\title{
STUDI KOMPARASI HUKUM PERTANGGUNG JAWABAN PIDANA DELIK PERDAGANGAN ORANG DITINJAU DARI KUHP DAN UNDANG-UNDANG NOMOR 21 TAHUN 2007 TENTANG PEMBERANTASAN TINDAK PIDANA PERDAGANGAN ORANG
}

\author{
Tri Santoso dan Emi Puasa Handayani \\ Fakultas Hukum Universitas Islam Kadiri \\ Email : emipuasa@gmail.com
}

\begin{abstract}
ABSTRAK
Pencegahan dan penanganan tindak pidana perdagangan manusia merupakan tanggung jawab Negara, pemerintah daerah beserta seluruh komponen masyarakat. Untuk mewujudkan langkah-langkah yang komprehensif dan terpadu dalam pelaksanaan pencegahan dan penanganan tersebut perlu dibentuk gugus tugas. Diperlukan kajian perbandingan (studi komparasi) antara KUHP dan Undang-Undang RI Nomor 21 Tahun 2007 dapat memberikan gambaran yang lebih jelas mengenai tindak pidana perdagangan manusia menurut kedua perspektif hukum tersebut, sehingga dapat tercapai suatu hasil yang objektif dan sesuai dengan tujuan penelitian. Rumusan masalah dalam penelitian ini adalah bagaimana pertanggung jawaban pidana delik perdagangan orang dalam KUHP dan Undang-Undang Nomor 21 Tahun 2007 tentang Pemberantasan Tindak Pidana Perdagangan Orang serta bagaimana komparasi hokum pertanggung jawaban pidana delik perdagangan orang dalam KUHP dan Undang-Undang Nomor 21 Tahun 2007 tentang Pemberantasan Tindak Pidana Perdagangan Orang. Adapun tujuan penelitian ini adalah untuk menganalisa pertanggung jawaban pidana delik perdagangan orang dalam KUHP dan Undang-Undang Nomor 21 Tahun 2007 tentang Pemberantasan Tindak Pidana Perdagangan Orang serta untuk menganalisa komparasi hukum pertanggung jawaban pidana delik perdagangan orang dalam KUHP dan Undang-Undang RI Nomor 21 Tahun 2007 tentang Pemberantasan Tindak Pidana Perdagangan Orang. Jenis atau tipologi penelitian ini menggunakan jenis penelitian legal research dengan pendekatan perbandingan hukum. Bahan hukum yang digunakan adalah bahan hukum primer yang terdiri dari peraturan perundang-undangan serta bahan hukum sekunder yang diperoleh dari bahan pustaka tentang tindak pidana perdagangan manusia melalui studi kepustakaan dan studi peraturan perundang-undangan.
\end{abstract}

Kata kunci : Perdagangan orang, KUHP, Undang-Undang Nomor 21 Tahun 2007. 


\section{Pendahuluan}

Perdagangan orang adalah bentuk modern dari perbudakan manusia (Modern Day Slavery) dan merupakan salah satu bentuk perlakuan terburuk dari pelanggaran harkat dan martabat manusia. ${ }^{1}$ Modern Day Slavery disini berarti pelaku memangsa korban yang berada dalam posisi rentan yang lemah secara ekonomi, fisik maupun emosional dan dengan menggunakan cara-cara yang modern untuk memberlakukan manusia layaknya budak. Praktek perdagangan orang sebenarnya di Indonesia sudah ada sejak lama, namun kurangnya kesadaran masyarakat dan belum adanya ketentuan yang komprehensif bagi penegak hukum serta kurang sensitifnya aparatur pemerintah menyebabkan tingginya kasus perdagangan orang. ${ }^{2}$

Pemahaman masyarakat terhadap tindak pidana perdagangan orang berhubungan dengan sikap kesadaran hukum mengenai pentingnya aturan yang berupa hukum positif, berhubungan dengan tingkat kesadaran hukum (rechtsbewustzijn), karena itu pemahaman terhadap hukum tidak hanya pada pengertian pemberlakuan perundangundangan (law inbook), tetapi lebih pada tataran implementasi (law in action), sehingga pemahaman terhadap tindak pidana perdagangan orang tidak hanya pada tataran konsep, tetapi lebih diutamakan pada tataran implementasi/penerapan yang berhubungan dengan kesadaran hukum. Apabila peraturan sudah dirasakan sebagai kebutuhan, maka akan menjadi perasaan hukum (rechtsgevoel), sehingga peraturan hukum akan dapat berlaku sesuai kebutuhan dan bukan karena keterpaksaan, dengan demikian tujuan hukum dan penegakan hukum akan berjalan sesuai dengan supremasi hukum. ${ }^{3}$

Mengingat fungsi hukum sebagai alat pembangunan dan pembaharuan masyarakat (law as a tool of social engineering), maka hukum juga berperan sebagai alat untuk mengubah masyarakat ke arah yang lebih baik. Kenyataan

1 Penjelasan atas Undang-Undang Nomor 21 Tahun 2007 tentang Pemberantasan Tindak Pidana Perdagangan Orang.

${ }^{2}$ Ibid, hlm. 15.

${ }^{3}$ Henny Nuraeny, Tindak Pidana Perdagangan Orang Kebijakan Hukum Pidana dan Pencegahannya, Jakarta: Sinar Grafika, 2011, hlm. 19 
yang ada sekarang, sebagian besar masyarakat kurang mempercayai hukum, baik terhadap aparat penegak hukum maupun lembaga peradilan, sehingga tindakan masyarakat cenderung main hakim sendiri. Tindakan ini diantaranya diakibatkan karena kurangnya kepercayaan masyarakat terhadap jaminan keadilan yang diberikan oleh hukum. ${ }^{4}$

Perdagangan orang yang mayoritas perempuan dan anak, merupakan jenis perbudakan pada era modern ini merupakan dampak krisis multidimensional yang dialami Indonesia, dalam pemberitaan saat ini sudah dinyatakan sebagai masalah global yang serius dan bahkan telah menjadi bisnis global yang telah memberikankeuntungan besar terhadap pelaku. Dari waktu ke waktu praktik perdagangan orang semakin menunjukan kualitas dan kuantitasnya. Setiap tahun diperkirakan dua juta manusia diperdagangkan dan sebagian besarnya perempuan dan anak. ${ }^{5}$

ILO Global Report on Forced Labour memperkirakan hampir 2,5 juta orang dieksploitasi melalui perdagangan orang menjadi buruh seluruh dunia, dan lebih dari setengahnya berada di wilayah Asia dan Pasifik dan $40 \%$ adalah anak-anak. Selanjutnya Internasional Organisation for Migration (IOM) yang telah memberikan bantuan bagi korban perdagangan orang menyatakan hampir 90 persen korban perdagangan orang adalah perempuan dimana lebih dari 25 persen adalah anak-anak yang memang paling rentan untuk diperdagangkan. Terjadinya eksploitasi terhadap perempuan dan anak ini dikarenakan kemiskinan struktural yang menyebabkan keluarga tidak dapat mengikuti kenaikan harga bahan pokok yang dengan demikian terpaksa mengirim anggota keluarganya termasuk perempuan dan anak-anak untuk bekerja. Bisnis perdagangan orang ini telah bersifat global dan telah memberikan keuntungan besar terhadap pelaku. Kenyataan bahwa yang lebih dominan menjadi korban adalah perempuan dan anak karena merekalah kelompok yang sering menjadi sasaran dan dianggap paling rentan. Korban perdagangan orang biasanya ditipu, diberlakukan tidak manusiawi dan

\footnotetext{
${ }^{4}$ Ibid, hlm. 20

${ }^{5}$ Rachmad Syafaat, Dagang Manusia, Jakarta: Lappera Pustaka Utama, 2003, hlm. 1
} 
dieksploitasi. Bentuk-bentuk eksploitasi itu sendiri di antaranya dengan cara memperlakukan korban untuk bekerja yang mengarah pada praktik-praktik eksploitasi seksual, perbudakan atau bentuk-bentuk perbudakan modern, perbuatan transplantasi organ tubuh untuk tujuan komersial, sampai penjualan bayi yang dimaksudkan untuk tujuan dan kepentingan mendapatkan keuntungan besar bagi para pelaku perdagangan orang.

Tindak pidana perdagangan orang merupakan tindak pidana awal untuk selanjutnya dapat berkembang ke arah tindak pidana lainnya yang terkait dengan perdagangan orang, sebagaimana telah disinggung di atas salah satunya adanya bentuk-bentuk eksploitasi seksual dalam hal ini perzinahan. Salah satu sebab adanya perdagangan orang karena lemahnya penindakan terhadap tindak pidana perzinahan. Perzinahan dalam KUHP sendiri diatur dalam Pasal 284 KUHP, di mana perzinahan itu sendiri merupakan delik aduan. Delik aduan menurut sifatnya dapat dibedakan menjadi dua yaitu:

1.1. Delik aduan yang absolut, yaitu delik yang menurut sifatnya dapat dituntut berdasarkan pengaduan, salah satu contohnya Pasal 284 KUHP tentang perzinahan.

1.2. Delik aduan yang relatif, disebut relatif karena dalam delik ini ada hubungan istimewa antara sipembuat dan orang yang terkena misalnya seorang anak yang mencuri uang dari ayahnya sendiri. ${ }^{6}$

Sejak awal Indonesia telah mengkriminalisasi perdagangan orang yang diatur dalam Pasal 297 KUHP, akan tetapi karena perdagangan orang sudah berkembang menjadi kejahatan transnasional yang terorganisir, maka diperlukan adanya pembaharuan komitmen untuk memerangi sebagaimana tertuang dalam Keppres Nomor 88 Tahun 2002 tentang Rencana Aksi Nasional Penghapusan Perdagangan Perempuan dan Anak dan gugus tugas yang beranggotakan lintas sektoral untuk implementasinya. Komitmen nasional ini bertujuan tidak hanya memerangi kejahatan perdagangan orang saja, tetapi juga kepada akar masalahnya yaitu kemiskinan, kurangnya

\footnotetext{
${ }^{6}$ Sudarto, Hukum Pidana I, Semarang : Yayasan Sudarto, 2009, hlm, 98
} 
pendidikan dan keterampilan, kurangnya akses, kesempatan dan informasi, serta nilai-nilai sosial budaya. ${ }^{7}$

Perkembangan tindak pidana perdagangan orang yang telah menjadi kejahatan transnasional, membuat pemerintah Indonesia mengambil suatu langkah kebijakan penegakan hukum pada tahun 2007 yaitu dengan mengeluarkan Undang-Undang Nomor 21 Tahun 2007 tentang Pemberantasan Tindak Pidana Perdagangan Orang. Upaya penegakan hukum menurut Suryono Sukanto dipengaruhi oleh beberapa faktor diantaranya : (i) faktor hukumnya sendiri, (ii) faktor penegakan hukum, (iii) faktor sarana atau fasilitas yang mendukung penegakan hukum, (iv) faktor masyarakat, yakni lingkungan dimana hukum tersebut berlaku atau diterapkan, dan (v) faktor kebudayaan. Kelima faktor tersebut di atas saling berkaitan erat karena merupakan esensi dari penegakan hukum serta merupakan tolok ukur dari efektivitas penegakan hukum.

Berbicara masalah penegakan hukum, sudah diketahui bersama bahwa peraturan perundang-undangan yang berlaku di Indonesia sebagian besar merupakan warisan zaman kolonial, di mana produk perundang-undangan tersebut seiring dengan perkembangan zaman saat ini sudah sangat tidak relevan lagi dengan kondisi saat ini, hal tersebut senada dengan apa yang dikemukakan oleh Moeljatno, walaupun Undang-undang Nomor 1 Tahun 1946 telah berusaha untuk menyesuaikan peraturan-peraturan hukum pidana dengan suasana kemerdekaan, namun pada hakikatnya asas-asas dan dasardasar tata hukum pidana dan hukum pidana masih tetap dilandaskan pada ilmu hukum pidana dan praktek hukum pidana kolonial yang mewajibkan adanya konkordansi dengan yang ada di negeri Belanda. ${ }^{8}$

Pernyataan Moeljatno tersebut, mengisyaratkan untuk segera dilakukannya pembaharuan dibidang hukum. Masalah pembaruan hukum (law reform) merupakan salah satu di antara banyak permasalahan hukum,

\footnotetext{
2010, hal. 7-8.

${ }^{7}$ Farhana, Aspek Hukum Perdagangan Orang di Indonesia, Jakarta: Sinar Grafika,

${ }^{8}$ Moeljatno dalam Barda Nawawi Arief, Beberapa Aspek Hukum Pengembangan Ilmu Hukum Pidana, Semarang: Pustaka Magister, 2011, hal. 12.
} 
terutama dihadapi oleh negara-negara yang sedang berkembang termasuk Indonesia. Pembangunan materi hukum di Indonesia diarahkan pada terwujudnya sistem hukum nasional yang mengabdi kepada kepentingan nasional. Penyusunan materi hukum secara menyeluruh harus bersumber pada Pancasila dan Undang-Undang Dasar 1945, khususnya penyusunan produk hukum-hukum baru yang sangat dibutuhkan untuk mendukung tugas umum pemerintahan dan pembangunan nasional. Penyusunan program legislasi dituntut dalam hal ini, penyusunan program lelislasi nasional terpadu sesuai dengan prioritas sangat diperlukan, termasuk upaya penggantian peraturan perundang-undangan warisan kolonial dengan peraturan perundang-undangan yang bersumber pada Pancasila dan Undang-Undang Dasar 1945.

Konsep pengaturan larangan ini seumur dengan pembentukan KUHP itu sendiri. Pasal 297 KUHP yang khusus mengatur perdagangan perempuan dan anak laki-laki di bawah umur yang menunjukkan bahwa pada masa penjajahpun perdagangan perempuan dan anak sudah dikualifikasi sebagai suatu kejahatan atau dianggap sebagai tindakan yang tidak manusiawi dan layak mendapatkan sanksi pidana. Namun seiring dengan kemajuan teknologi, informasi, transportasi yang mengakselerasi globalisasi pelaku (Traffwker) perdagangan orang dengan cepat berkembang menjadi sindikasi lintas batas negara yang dengan sangat halus menjerat mangsanya, tetapi dengan sangat kejam mengeksploitasinya dengan berbagai cara sehingga korban menjadi tidak berdaya untuk membebaskan diri. Tindak pidana perdagangan manusia khususnya perempuan dan anak telah meluas dalam bentuk jaringan kejahatan baik terorganisasi maupun tidak terorganisasi. Tindak pidana perdagangan manusia bahkan melibatkan tidak hanya perorangan tetapi juga korporasi dan penyelenggaraan negara yang menyalahgunakan wewenang dan kekuasaannya. Jaringan pelaku tindak pidana perdagangan manusia memiliki jangkauan operasi tidak hanya antar wilayah dalam negeri tetapi juga antar negara. 
Ketentuan Pasal 297 KUHP tersebut tidak merumuskan pengertian perdagangan manusia secara tegas dan memberikan sanksi yang terlalu ringan dan tidak sepadan dengan dampak yang diderita korban akibat kejahatan perdagangan manusia. Selanjutnya pada tanggal 17 April 2007 pemerintah Indonesia akhirnya mengesahkan dan mengundangkan Undang-Undang Nomor 21 Tahun 2007 tentang tentang Pemberantasan Tindak Pidana Perdagangan Orang yang mengatur secara khusus tentang tindak pidana perdagangan orang. Undang-Undang ini diharapkan mampu menyediakan landasan hukum formil dan materiil sekaligus untuk mengantisipasi dan menjerat semua jenis tindakan dalam proses, cara atau semua bentuk eksploitasi yang mungkin terjadi dalam praktek perdagangan manusia, baik yang dilakukan antar wilayah dalam negeri maupun antar negara, baik oleh pelaku perorangan maupun korporasi.

Dalam Undang-Undang ini juga memberikan perhatian yang besar terhadap penderitaan korban sebagai akibat tindak pidana perdagangan manusia dalam bentuk hak restitusi yang harus harus diberikan oleh pelaku tindak pidana perdagangan orang sebagai ganti kerugian bagi korban. Undang-Undang ini mengatur juga hak korban atas rehabilitasi medis dan sosial, pemulangan serta reintegrasi yang harus dilakukan oleh negara khususnya bagi mereka yang mengalami penderitaan fisik, psikis, dan sosial akibat tindak pidana perdagangan orang. Pencegahan dan penanganan tindak pidana perdagangan manusia merupakan tanggung jawab pemerintah, pemerintah daerah, masyarakat, dan keluarga. Untuk mewujudkan langkahlangkah yang komprehensif dan terpadu dalam pelaksanaan pencegahan dan penanganan tersebut perlu dibentuk gugus tugas. Tindak pidana perdagangan orang merupakan kejahatan yang tidak saja terjadi dalam satu wilayah negara melainkan juga antar negara. Oleh karena itu, perlu dikembangkan kerja sama internasional dalam bentuk perjanjian bantuan timbal balik dalam masalah pidana dan/atau kerja sama teknis lainnya sesuai dengan ketentuan peraturan perundang-undangan. 


\section{Rumusan Masalah}

2.1. Bagaimana pertanggung jawaban pidana delik perdagangan orang dalam KUHP dan Undang-Undang Nomor 21 Tahun 2007 tentang Pemberantasan Tindak Pidana Perdagangan Orang.

2.2. Bagaimana komparasi pertanggung jawaban pidana delik perdagangan orang dalam KUHP dan Undang-Undang Nomor 21 Tahun 2007 tentang Pemberantasan Tindak Pidana Perdagangan Orang.

\section{Tujuan Penelitian}

3.1. Untuk menganalisa pertanggung jawaban pidana delik perdagangan orang dalam KUHP dan Undang-Undang Nomor 21 Tahun 2007 tentang Pemberantasan Tindak Pidana Perdagangan Orang.

3.2. Untuk menganalisa komparasi pertanggung jawaban pidana delik perdagangan orang dalam KUHP dan Undang-Undang Nomor 21 Tahun 2007 tentang Pemberantasan Tindak Pidana Perdagangan Orang.

\section{Metode Penelitian}

\subsection{Jenis Penelitian}

Jenis penelitian yang digunakan adalah Legal Research, yaitu penelitian terhadap perbandingan hukum, dimana memperbandingkan secara komprehensif antara KUHP (Undang-Undang yang bersifat umum) dengan Undang-undang nomor 21 Tahun 2007 (Undang-Undang yang bersifat khusus) yang berkaitan dengan rumusan tindak pidananya, pertanggungjawaban pidana dan sanksi pidana bagi pelaku delik perdagangan manusia.

\subsection{Pendekatan Penelitian}

Metode pendekatan yang dipakai dalam penelitian ini menggunakan pendekatan perbandingan hukum. Penelitian yang dimaksudkan untuk mencari, meneliti dan mengkaji secara mendalam rumusan norma dan aturan mengenai tindak pidana, pertanggungjawaban pidana dan sanksi pidana bagi pelaku perdagangan manusia dalam KUHP maupun UndangUndang Nomor 21 Tahun 2007. Kemudian kedua norma dan aturan 
yang berbeda tersebut diperbandingkan atau dikomparasikan dengan cara melihat sisi-sisi persamaan dan perbedaan diantara keduanya untuk memperoleh jawabannya yang objektif dan hasilnya sesuai dengan tujuan penelitian.

\subsection{Bahan Hukum}

Bahan hukum primer yang terdiri dari Kitab Undang-Undang Hukum Pidana, Undang- Undang Republik Indonesia No. 21 Tahun 2007 tentang Pemberantasan Tindak Pidana Perdagangan Orang dan peraturan perundang-undangan yang terkait sebagai hukum positif Indonesia.

Bahan hukum sekunder, yaitu data yang menjelaskan analisa dan pendukung pada bahan hukum primer yang terdiri dari sumber-sumber tulisan mengenai tindak pidana perdagangan manusia dalam perspektif KUHP dan UU RI No. 21 Tahun 2007, yang terdapat dalam buku, hasilhasil penelitian, dan lain-lain yang berguna bagi penelitian.

\subsection{Teknik Pengumpulan Data}

Untuk mendapatkan data dilakukan dengan jalan studi pustaka. Hal ini dilakukan dengan identifikasi literatur buku, peraturan perundangundangan dan literatur lain yang berkaitan dengan masalah yang diteliti. Menurut Soerjono Soekanto, studi kepustakaan adalah studi dokumen yang merupakan suatu alat pengumpulan data yang dilakukan atas data tertulis. Dalam hal ini, peneliti membaca, mempelajari dan mengkaji dari buku-buku, dokumen dan bahan tulisan yang berhubungan dengan penelitian yang akan diadakan. ${ }^{9}$

\subsection{Analisa Penelitian}

Teknik analisis data adalah tahap yang penting dalam menentukan suatu penelitian. Analisis data dalam suatu penelitian adalah menguraikan atau memecahkan masalah yang diteliti berdasarkan data yang diperoleh

\footnotetext{
${ }^{9}$ Soerjono Soekanto, Pengantar Penelitian Hukum, Jakarta: UI Press. 1984, hlm. 21
} 
kemudian diolah ke dalam pokok permasalahan yang diajukan terhadap penelitian yang bersifat deskriptif. ${ }^{10}$

\section{Hasil Penelitian dan Pembahasan}

5.1. Pertanggung Jawaban Pidana Delik Perdagangan Orang dalam KUHP

Sebelum membahas tindak pidana perdagangan orang dalam KUHP terlebih dahulu kita harus mengetahui pengertian apa itu tindak pidana. Pembentuk Undang-Undang telah menggunakan perkataan "strafbaarfeit" untuk menyebutkan apa yang kita kenal sebagai "tindak pidana" didalam kitab Undang-Undang Hukum Pidana tanpa memberikan sesuatu penjelasan mengenai apa yang sebenarnya yang dimaksud dengan perkataan "strafbaarfeit" tersebut.

Perkataan "feit" itu sendiri dalam bahasa Belanda berarti "sebagian dari suatu kenyataan" sedangkan "strafbaar" berarti "dapat dihukum" hingga secara harafiah perkatan "strafbaarfeit" itu dapat diterjemahkan sebagai "sebagian dari suatu kenyataan yang dapat dihukum", yang sudah barang tentu tidak tepat, oleh karena kelak akan kita ketahui bahwa yang dapat dihukum itu sebenarnya adalah manusia sebagai pribadi dan bukan kenyataan, perbuatan, ataupun tindakan. ${ }^{11}$

Oleh karena itu seperti yang telah dikatakan di atas, bahwa pembentuk Undang-Undang kita tidak memberikan sesuatu penjelasan mengenai apa yang sebenarnya telah ia maksud dengan perkataan "strafbaarfeit" maka timbulah didalam doktrin berbagai pendapat tentang apa yang sebenarnya yang dimaksud dengan "strafbaarfeit" tersebut. ${ }^{12}$.

Simons menerangkan bahwa "strafbaarfeit" adalah kelakuan yang diancam dengan pidana yang bersifat melawan hukum yang berhubungan

\footnotetext{
${ }^{11}$ Moeljatno, Asas-Asas Hukum Pidana, Jakarta : Rineka Cipta, 1993, hlm. 16

${ }^{12}$ P.A.F. Lamintang, Dasar-Dasar Hukum Pidana Indonesia. Bandung : PT Citra
} 1998, hlm. 8

${ }^{10}$ Heribertus Sutopo, Pengantar Penelitian Kualitatif, Surakarta: Puslitbang UNS. Aditya Bakti, 1997, hlm. 57 
dengan kesalahan dan dilakukan oleh orang yang mampu bertanggungjawab. ${ }^{13}$

Menurut Pompe, tindak pidana atau "strafbaarfeit sebagai suatu pelangaran norma (gangguan tehadap tertib hukum) yang dengan sengaja atau tidak dengan sengaja telah dilakukan oleh seorang pelaku, dimana penjatuhan hukuman terhadap pelaku tersebut adalah perlu demi terpeliharanya tertib hukum dan terjaminnya kepentingan umum. ${ }^{14}$

Menurut Van Hattum, tindak pidana atau "strafbaarfeit" dikarenakan sebagai suatu tindakan yang karena telah melakukan tindakan semacam itu membuat seseorang menjadi dapat dihukum. ${ }^{15}$ Perbuatan pidana atau tindak pidana dapat kita disamakan dengan istilah Inggris "criminal act" yang berarti kelakuan dan akibat, atau dengan kata lain perkataan : akibat dari suatu kelakuan yang dilarang oleh hukum.

Ada pembagian-pembagian dari tindak pidana salah satunya adalah delik formal dan delik material. Pada umumnya rumusan-rumusan delik didalam Kitab Undang Hukum Pidana itu merupakan rumusan-rumusan dari apa yang disebut valtooid delik, yakni delik yang telah selesai dilakukan oleh pelaku yang sebenarnya. Delik formal adalah delik yang telah dianggap selesai dengan dilakukannya tindakan yang dilarang dan diancam oleh hukuman dengan Undang-Undang. Delik material adalah delik yang dianggap telah selesai dengan ditimbulkannya akibat yang dilarang dan diancam dengan hukuman oleh Undang-Undang. ${ }^{16}$

Tindak pidana perdagangan orang memang tidak dirumuskan secara jelas dalam KUHP tetapi ada beberapa Pasal dalam KUHP yang dapat digunakan untuk menjerat pelaku tentunya yang ada kaitannya dengan perdagangan orang. Diantaranya akan dijelaskan sebagai berikut :

1) Perbudakan dan penghambaan telah dinyatakan sebagai tindakan yang melanggar hukum dan dinyatakan sebagai

\footnotetext{
${ }^{13}$ Moeljatno, Asas-Asas Hukum Pidana. Jakarta : Rineka Cipta, 1993, hlm. 57

${ }^{14} \mathrm{Ibd}$, hlm. 178

${ }^{15} \mathrm{Ibid}, \mathrm{hlm} .184$

${ }^{16}$ Ibid, hlm. 212
} 
kejahatan terhadap kemerdekaan orang, sebagaimana termaktub dalam Kitab Undang-undang Hukum Pidana (Wet boek van Strafrecht yang terakhir diubah dengan Undangundang RI No. 1 Tahun 1946) yang mengatur :

a) Pasal 324: Barangsiapa dengan biaya sendiri atau biaya orang lain menjalankan perniagaan budak atau dengan sengaja turut serta secara langsung atau tidak langsung dalam salah satu perbuatan tersebut di atas, diancam dengan pidana penjara paling lama dua belas tahun.

b) Pasal 333 (1): Barang siapa dengan sengaja dan melawan hukum merampas kemerdekaan seseorang atau meneruskan perampasan kemerdekaan yang demikian, diancam dengan pidana penjara paling lama delapan tahun.

c) Pasal 333 (2): Jika perbuatan itu mengakibatkan luka-luka berat, maka yang bersalah diancam dengan pidana penjara paling lama sembilan tahun.

d) Pasal 333 (3): Jika mengakibatkan mati, diancam dengan pidana penjara paling lama dua belas tahun.

e) Pasal 333 (4): Pidana yang ditentukan dalam Pasal ini diterapkan juga bagi orang yang dengan sengaja dan melawan hukum memberi tempat untuk perampasan kemerdekaan.

2) Perbudakan dan penghambaan dalam bentuk perdagangan orang juga dikriminalisasi dalam sistem hukum Indonesia sebagaimana termaktub dalam Kitab Undang-undang Hukum Pidana (KUHP) Pasal 297 yang berbunyi : "Perdagangan wanita dan perdagangan anak laki-laki yang belum dewasa, diancam dengan pidana penjara paling lama enam tahun"

3) Salah satu kegiatan yang mendorong timbulnya perdagangan orang adalah pelacuran. Di Indonesia 'kegiatan melacur' tidak 
secara eksplisit dinyatakan sebagai tindak pidana, Namun mendapatkan keuntungan dan melacurkan orang lain adalah tindakan yang dianggap kejahatan terhadap kesusilaan atau pelanggaran terhadap ketertiban umum, sebagaimana termaktub dalam KUHP sebagai berikut:

a) Dalam Buku Kedua. Kejahatan, Bab XIV. Kejahatan terhadap Kesusilaan:

(1) Pasal 289 :Barangsiapa dengan kekerasan atau ancaman kekerasan memaksa seseorang untuk melakukan atau membiarkan dilakukan perbuatan cabul, diancam karena melakukan perbuatan yang menyerang kehormatan kesusilaan, dengan pidana penjara paling lama sembilan tahun.

(2) Pasal 296: Barangsiapa dengan sengaja menyebabkan atau memudahkan perbutan cabul dengan orang lain, dan menjadikannya sebagai pencaharian atau kebiasaan, diancam dengan pidana penjara paling lama satu tahun empat bulan atau pidana denda paling banyak seribu rupiah.

b) Dalam Buku Ketiga. Pelanggaran, Bab II. Pelanggaran Ketertiban Umum: Pasal 506: Barangsiapa menarik keuntungan dari perbuatan cabul seorang wanita dan menjadikannya sebagai pencaharian, diancam dengan pidana kurungan paling lama satu tahun.

Secara umum dari penjelasan tersebut di atas tindak pidana yang terkait dengan perdagangan orang dalam KUHP dapat diklasifikasikan menjadi berbagai bentuk tindak pidana. Sebagai berikut :

1) Tindak pidana materiil, yang terdapat dalam Pasal 333 (2) yaitu mengakibatkan luka-luka berat, 333 (3) yaitu mengakibatkan mati.

2) Tindak pidana formil yang terdapat dalam Pasal 324, 333 (1), 
3) $297,296,289$, dan 506.

4) Tindak pidana penyertaan (turut serta), yang terdapat dalam Pasal 324.

5) Tindak pidana pembantuan, yang terdapat dalam Pasal 333 (4).

5.2. Pertanggung Jawaban Pidana Delik Perdagangan Orang dalam UndangUndang RI Nomor 21 Tahun 2007 tentang Pemberantasan Tindak Pidana Perdagangan Orang.

Menurut perumusan dalam Undang-Undang ini, tindak pidana dibedakan menjadi dua yaitu tindak pidana formil dan tindak pidana materiil. Tindak pidana formil adalah tindak pidana yang perumusannya ditiikberatkan kepada perbuatan yang dilarang, tindak pidana ini selesai dengan dilakukannya perbuatan yang dirumuskan dalam Undang-Undang sedangkan tindak pidana materiil adalah tindak pidana yang perumusannya dititikberatkan kepada akibat yang dilarang. Tindak pidana ini selesai apabila akibat yang dilarang itu timbul.

Tindak pidana perdagangan orang ditinjau dari Undang-undang Nomor 21 tahun 2007 adapun pengertiannya terdapat dalam Pasal 1 ke-2, yaitu : "tindak pidana perdagangan orang adalah setiap tindakan atau serangkaian tindakan yang memenuhi unsur-unsur tindak pidana yang ditentukan dalam Undang-Undang ini". Yaitu Setiap tindakan atau serangkaian tindakan yang memenuhi unsur-unsur tindak pidana yang ditentukan dalam Pasal 2-7 Undang-Undang Nomor 21 tahun 2007.

Berikut adalah Pasal-Pasal 2-7 dalam Undang-Undang Nomor 21 tahun 2007 yang memenuhi unsur-unsur tindak pidana perdagangan orang antara lain :

5.2.1. Pasal 2 ayat (1), yaitu setiap orang yang melakukan perekrutan, pengangkutan, penampungan, pengiriman, pemindahan, atau penerimaan seseorang dengan ancaman kekerasan, pengunaan kekerasan, penculikan penyekapan, pemalsuan, penipuan, penyalahgunaan kekuasaan atau posisi rentan, penjeratan utang, atau memberi bayaran atau 
manfaat walaupun memperoleh persetujuan dari orang yang memegang kendali atas orang lain, untuk tujuan mengekploitasi orang tersebut diwilayah negara Republik Indonesia, dipidana dengan pidana penjara paling singkat 3 tahun dan paling lama 15 tahun dan pidana denda paling sedikit seratus dua puluh juta rupiah dan paling banyak enam ratus juta rupiah. Pasal ini merupakan tindak pidana formil.

5.2.2. Pasal 2 ayat (2), yaitu jika perbuatan sebagaimana dimaksud pada ayat (1) mengakibatkan orang terekploitasi, maka pelaku dipidana yang sama sebagaimana dimaksud pada ayat (1). Pasal ini merupakan tindak pidana materiil karena mengakibatkan orang tereksploitasi.

5.2.3. Pasal 3, yaitu setiap orang yang memasukkan orang kewilayah negara Rebuplik Indonesia dengan maksud untuk diekploitasi di wilayah negara Republik Indonesia atau diekploitasi diwilayah negara lain dipidana dengan pidana penjara paling singkat 3 tahun dan paling lama 15 tahun dan denda paling sedikit 120 juta rupiah dan paling banyak 600 juta rupiah. Pasal ini merupakan tindak pidana formil.

5.2.4. Pasal 4, yaitu setiap orang yang membawa warga negara Indonesia keluar wilayah negara Republik Indonesia dengan maksud untuk diekploitasi diluar wilayah negara Republik Indonesia dipidana dengan pidana penjara paling singkat 3 tahun dan paling lama 15 tahun dan denda paling sedikit 120 juta rupiah dan paling banyak 600 juta rupiah. Pasal ini merupakan tindak pidana formil.

5.2.5. Pasal 5, setiap orang yang melakukan pengangkatan anak dengan menjanjikan sesuatu atau memberikan sesuatu dengan maksud untuk dieksploitasi dipidana dengan pidana penjara paling singkat 3 tahun dan paling lama 15 tahun dan 
denda paling sedikit 120 juta rupiah dan paling banyak 600 juta rupiah. Pasal ini merupakan tindak pidana formil.

5.2.6. Pasal 6, yaitu setiap orang yang melakukan pengiriman anak kedalam atau keluar negeri dengan cara apapun yang mengakibatkan anak tersebut tereksploitasi dipidana dengan pidana penjara paling singkat 3 tahun dan paling lama 15 tahun dan denda paling sedikit 120 juta rupiah dan paling banyak 600 juta rupiah. Pasal ini merupakan tindak pidana materiil karena mengakibatkan anak tereksploitasi.

5.2.7. Pasal 7 ayat (1), yaitu jika tindak pidana sebagaimana dimaksud dalam Pasal 2 ayat (2), Pasal 3, Pasal 4, Pasal 5, Pasal 6 mengakibatkan korban menderita luka berat, gangguan jiwa berat, penyakit ,menular lainnya yang membahayakan jiwanya, kehamilan, atau terganggu atau hilangnya fungsi reproduksinya maka ancaman pidananya ditambah sepertiga dari ancaman pidana dalam Pasal 2 ayat (2), Pasal 3, Pasal 4, Pasal 5, Pasal 6. Pasal ini merupakan tindak pidana materiil karena menimbulkan akibat kepada korban.

5.2.8. Pasal 7 ayat (2), yaitu jika tindak pidana sebagaimana dimaksud dalam Pasal 2 ayat (2), Pasal 3, Pasal4, Pasal 5, Pasal 6, mengakibatkan matinya korban, dipidana dengan pidana penjara paling singkat 5 tahun dan paling lam penjara seumur hidup dan denda paling sedikit 200 juta rupiah dan paling banyak 5 milyar rupiah. Pasal ini merupakan tindak pidana materiil karena mengakibatkan matinya korban.

5.2.9. Pasal 9, yaitu setiap orang yang berusaha mengerakkan orang lain supaya melakukan tindak pidana perdagangan orang, dan tindak pidana itu tidak terjadi, dipidana dengan pidana penjara paling singkat 1 tahun dan paling lama 6 
tahun dan pidana denda paling sedikit 40 juta rupiah dan paling banyak 240 juta rupiah. Pasal ini merupakan tindak pidana menggerakkan.

5.2.10. Pasal 10, yaitu setiap orang yang membantu atau melakukan percobaan untuk melakukan tindak pidana perdagangan orang, dipidana dengan pidana yang sama sebagai pelaku sebagaimana dimaksud dalam Pasal 2, Pasal 3, Pasal 4, Pasal 5, Pasal 6. Pasal ini merupakan tindak pidana pembantuan dan percobaan.

5.2.11. Pasal 11, yaitu setiap orang yang merencanakan atau melakukan permufakatan jahat untuk melakukan tindak pidana perdagangan orang dipidana dengan pidana yang sama sebagai pelaku sebagaimana dimaksud dalam Pasal 2, Pasal 3, Pasal 4, Pasal 5, dan Pasal 6. Pasal ini merupakan tindak pidana perencanaan dan permufakatan jahat.

5.2.12. Pasal 12, yaitu setiap orang yang menggunakan atau memanfaatkan korban tindak pidana perdagangan orang, dengan cara melakukan persetubuhan atau perbuatan cabul lainnya dengan korban tindak pidana perdagangan orang, mempekerjakan korban tindak pidana perdagangan orang untuk meneruskan praktek eksploitasi atau mengambil keuntungan dari hasil tindak pidana perdagangan orang dipidana dengan pidana yang sama sebagaimana dimaksud dalam Pasal 2 , Pasal 3, Pasal 4, Pasal 5, dan Pasal 6. Pasal ini merupakan tindak pidana menggunakan atau memanfaatkan.

Secara umum dari penjelasan tersebut di atas tindak pidana perdagangan orang dalam Undang-Undang Nomor 21 tahun 2007 dapat diklasifikasi menjadi berbagai bentuk tindak pidana sebagai berikut :

5.2.1. Tindak pidana materiil yang terdapat dalam Pasal 2 ayat (2), 6, 7 ayat (1), dan 7 ayat (2). 
5.2.2. Tindak pidana formil yang terdapat dalam Pasal 2 ayat (1), 3,4 , dan 5 .

5.2.3. Tindak pidana percobaan yang terdapat dalam Pasal 10.

5.2.4. Tindak pidana pembantuan yang terdapat dalam Pasal 10 dan 23.

5.2.5. Tindak pidana menyalahgunakan kekuasaan yang terdapat dalam Pasal 8.

5.2.6. Tindak pidana menggerakkan yang terdapat dalam Pasal 9.

5.2.7. Tindak pidana perencanaan dan permufakatan jahat yang terdapat dalam Pasal 11.

5.2.8. Tindak pidana menggunakan atau memanfaatkan yang terdapat dalam Pasal 12.

5.3. Komparasi Pertanggungjawaban Pidana Delik Perdagangan Orang dalam KUHP dan Undang-Undang Nomor 21 Tahun 2007 tentang Pemberantasan Tindak Pidana Perdagangan Orang.

5.3.1. Pengertian pertanggungjawaban pidana ditinjau dari KUHP dan Undang-Undang Nomor 21 Tahun 2007 tentang Pemberantasan Tindak Pidana Perdagangan Orang.

Dalam KUHP dan Undang-Undang Nomor 21 Tahun 2007 tidak terdapat rumusan tentang pengertian pertanggungjawaban pidana dan kemampuan bertanggungjawab, oleh karena itu pengertian tersebut harus kita cari dalam dunia ilmu hukum (doktrin). Berbicara tentang pertanggungjawaban pidana, maka tidak dapat dilepaskan dengan adanya tindak pidana. Tindak pidana tidak berdiri sendiri, itu baru bermakna manakala terdapat pertanggungjawaban pidana. Ini berarti setiap orang yang melakukan tindak pidana tidak dengan sendirinya harus dipidana. Untuk dapat dipidana harus ada pertanggungjawaban pidana. Pertanggungjawaban pidana lahir dengan diteruskannya celaan yang obyektif terhadap perbuatan yang dinyatakan sebagai tindak pidana berdasarkan hukum pidana yang berlaku dan secara 
subjektif kepada pembuat yang memenuhi persyaratan untuk dapat dikenai pidana karena perbuatan tersebut.

Dasar adanya tindak pidana adalah asas legalitas sedangkan dasar dapat dipidananya pembuat adalah tiada pidana tanpa kesalahan. Ini berarti bahwa pembuat tindak pidana hanya akan dipidana jika ia mempunyai kesalahan dalam melakukan tindak pidana tersebut. $^{17}$

Sudarto menyatakan "dipidananya seseorang tidaklah cukup apabila orang itu telah melakukan perbuatan yang bertentangan dengan hukum atau bersifat melawan hukum. Jadi meskipun perbuatan tersebut memenuhi rumusan delik dalam UndangUndang dan tidak dibenarkan, namun hal tersebut belum memenuhi syarat untuk penjatuhan pidana. Untuk pemidanaan masih perlu adanya syarat untuk penjatuhan pidana. Untuk pemidanaan masih perlu adanya syarat, bahwa orang yang melakukan perbuatan itu mempunyai kesalahan atau bersalah. Dengan perbuatan lain, orang tersebut harus dapat dipertanggungjawabkan atas perbuatannya atau jika dilihat dari sudut perbuatannya perbuatannya baru dapat dipertanggungjawabkan kepada orang tersebut". ${ }^{18}$

Simon mengatakan bahwa kesalahan adalah keadaan psikis orang yang melakuan perbuatan dan hubungannya dengan perbuatan yang dilakukan, yang sedemikian rupa sehingga orang itu dapat dicela karena perbuatan tadi. ${ }^{19}$ Jadi yang harus diperhatikan adalah (1). Keadaan batin dari orang yang melakukan perbuatan itu. (2). Hubungan antara keadaan batin itu dengan perbuatan yang dilakukan. Hal yang pertama yaitu

${ }^{17}$ Dwidja Priyatno, Kebijakan Legislasi Tentang Sistem Pertanggung jawaban Pidana Korporasi di Indonesia, Bandung : CV Utomo, 2004, hlm. 30

${ }^{18} \mathrm{Ibid}, \mathrm{hlm} .31$

${ }^{19}$ Roeslan Saleh, Perbuatan Pidana dan Pertanggungjawaban Pidana, Jakarta : Aksara Baru, 1983, hlm. 78 
mengenai keadaan batin dari orang yang melakukan perbuatan, dalam ilmu hukum pidana merupakan soal yang lazim disebut masalah kemampuan bertanggungjawab, hal yang kedua yaitu mengenai hubungan antara batin itu dengan perbuatan yang dilakukan merupakan masalah kesengajaan, kealpaan, serta alasan pemaaf, sehingga mampu bertanggungjawab, mempunyai kesengajaan atau kealpaan serta tidak adanya alasan pemaaf merupakan unsur-unsur dari kesalahan. Tiga unsur ini merupakan unsur yang tidak dapat dipisah-pisahkan. Yang satu bergantung pada yang lain. Konkritnya tidaklah mungkin dapat dipikirkan tentang adanya kesengajaan ataupun kealpaan apabila orang itu tidak mampu bertanggungjawab, begitu pula tidak dapat dipikirkan mengenai alasan pemaaf apabila orang tidak mampu bertanggungjawab, dan tidak pula adanya kesengajaan ataupun kealpaan

Dalam KUHP memang tidak ada rumusan yang tegas tentang kemampuan bertanggungjawab pidana. Pasal 44 ayat (1) KUHP justru merumuskan tentang keadaan mengenai bilamana seseorang tidak mampu bertanggungjawab agar tidak dipidana, artinya merumuskan kebalikan secara negative dari kemampuan bertanggungjawab. ${ }^{20}$

Dua keadaan jiwa yang tidak mampu bertanggungjawab sebagaimana yang dirumuskan didalam Pasal 44 ayat (1) KUHP, yakni jiwanya cacat dalam pertumbuhannya dan jiwanya terganggu karena penyekit. Orang yang dalam keadaan demikian jika melakukan tindak pidana tidak boleh dipidana. ${ }^{21}$

${ }^{20}$ Adami Chazawi, Pelajaran Hukum Pidana Bagian 2, Jakarta : PT Raja Grafindo Persada, 2002, hlm. 142

${ }^{21}$ Ibid, hlm. 143 
Menurut Moelyatno ada dua syarat seseorang dikatakan mempunyai kemampuan bertanggungjawab, yaitu :

5.3.1.1. Harus adanya kemampuan untuk membedabedakan antara perbuatan yang baik dengan perbuatan yang buruk, yang sesuai hukum dan yang melawan hukum.

5.3.1.2. Harus ada kemampuan untuk menentukan kehendaknya menurut keinsyafan tentang baik dan buruknya perbuatan tadi. $^{22}$

Kemampuan untuk membeda-bedakan antara yang baik dan yang buruk merupakan faktor akal yaitu dapat membeda-bedakan antara perbuatan yang diperbolehkan dan perbuatan yang tidak diperbolehkan, sedangkan yang kedua adalah faktor perasaan atau kehendak yaitu dapat menyesuaikan tingkah lakunya dengan keinsyafan atas nama yang diperbolehkan dan mana yang tidak diperbolehkan. Konsekuensi bagi orang yang tidak mampu menentukan kehendaknya menurut keinsyafan tentang baik dan buruknya perbuatan tadi, ia tidak mempunyai kesalahan, sehingga perbuatan yang dilakukan merupakan perbuatan pidana, tidak dapat dipertanggunngjawabkan kepadanya. ${ }^{23}$

Menurut Adami Chazawi orang yang mampu bertanggungjawab itu ada tiga syarat yang harus dipenuhi yaitu :

5.3.1.1. Keadaan jiwa seseorang yang sedemikian rupa (normal) sehingga ia bebas atau mempunyai kemampuan dalam menentukan kehendaknya terhadap perbuatan yang ia akan lakukan.

5.3.1.2. Keadaan jiwa orang itu yang sedemikian rupa, sehingga ia mempunyai kemampuan untuk dapat

\footnotetext{
${ }^{22}$ Moeljatno, Asas-Asas Hukum Pidana, Jakarta : Rineka Cipta, 1993, hlm. 176

${ }^{23}$ Ibid, hlm. 165
} 
mengerti terhadap nilai perbuatannya beserta akibatnya.

5.3.1.3. Keadaan jiwa orang itu sedemikian rupa, sehingga ia mampu untuk menyadari, menginsyafi bahwa perbuatan yang akan dilakukannya itu adalah suatu kelakuan yang tercela, kelakuan yang tidak dibenarkan oleh hukum, atau oleh masyarakat maupun tata susila. ${ }^{24}$

Dalam Rancangan KUHP Pasal 32 ayat (2) dimungkinkan dalam hal tertentu seseorang dapat dipertanggungjwabakan atas tindak pidana yang dilakukan oleh orang lain, jika ditentukan dalam suatu Undang-Undang. Ketentuan ini merupakan pengecualian dari asas tiada pidana tanpa kesalahan. Dalam halhal tertentu tanggungjawab seseorang dipandang patut diperluas sampai kepada tindakan bawahannya yang melakukan pekerjaan atau perbuatan untuknya atau dalam batas-batas perintahnya. Oleh karena itu meskipun dalam kenyataannya orang tidak melakukan tindak pidana namun dalam rangka pertanggungjawaban pidana ia dipandang mempunyai kesalahan jika perbuatan orang lain yang berada dalam kedudukan yang sedemikian itu merupakan tindak pidana.

Asas pertanggungjawaban yang bersifat pengecualian ini dikenal dengan asas "Vicarious Liability" sering diartikan pertanggungjawaban menurut hukum seseorang atas perbuatan salah yang dilakukan oleh orang lain. ${ }^{25}$

Pengecualian lainya juga terdapat dalam Pasal 32 ayat (3) Rancangan KUHP yang menyatakan untuk tindak pidana tertentu Undang-Undang dapat menentukan bahwa seseorang dapat

${ }^{24}$ Adami Chazawi, Pelajaran Hukum Pidana Bagian 2, Jakarta : PT Raja Grafindo Persada, 2002, hlm. 165

${ }^{25}$ Dwidja Priyatno, Kebijakan Legislasi Tentang Sistem Pertanggungjawaban Pidana Korporasi di Indonesia, Bandung : CV Utomo, 2004, hlm. 49 
dipidana semata-mata karena telah dipenuhinya unsur-unsur tindak pidana tersebut tanpa memperhatikan adanya kesalahan.

Ketentuan ayat ini merupakan suatu pengecualian. Oleh karena itu tidak berlaku juga bagi semua tindak pidana melainkan hanya untuk tindak pidana tertentu yang ditetapkan oleh UndangUndang. Untuk tindak pidana tertentu tersebut pembuat telah dapat dipidana hanya karena telah dipenuhinya unsur-unsur tindak pidana oleh perbuatannya. Disini kesalahan pembuat dalam melakukan perbuatan tersebut tidak lagi diperhatikan. Ketentuan dalam ayat ini sering dikenal dengan asas "Strict Liability" atau disebut dengan pertanggungjawaban tanpa kesalahan. ${ }^{26}$

5.3.2. Pertanggungjawaban Pidana Bagi Pelaku Perdagangan Orang Menurut KUHP dan Undang-Undang Nomor 21 Tahun 2007 tentang Pemberantasan Tindak Pidana Perdagangan Orang.

\subsubsection{Kitab Undang-Undang Hukum Pidana.}

Dalam Bab II telah disinggung bahwa, dalam KUHP dan Undang-Undang Nomor 21 Tahun 2007 tidak didapat rumusan tentang pengertian pertanggungjawaban pidana dan kemampuan bertanggungjawab, oleh kerena itu pengertian tersebut harus kita cari dalam dunia ilmu hukum (doktrin).

Berbicara tentang pertanggungjawaban pidana, maka tidak dapat dilepaskan dengan adanya tindak pidana. Tindak pidana tidak berdiri sendiri, itu baru bermakna manakala terdapat pertanggungjawaban pidana. Ini berarti setiap orang yang melakukan tindak pidana tidak dengan sendirinya harus dipidana. Untuk dapat dipidana harus ada pertanggungjawaban pidana. Pertanggungjawaban pidana lahir dengan diteruskannya celaan yang obyektif terhadap perbuatan yang

\footnotetext{
${ }^{26}$ Ibid, hlm. 50
} 
dinyatakan sebagai tindak pidana berdasarkan hukum pidana yang berlaku, dan secara subyektif kepada pembuat yang memenuhi persyaratan untuk dapat dikenai pidana karena perbuatan tersebut.

Dasar adanya tindak pidana adalah asas legalitas sedangkan dasar dapat dipidananya pembuat adalah tiada pidana tanpa kesalahan. Ini berarti bahwa pembuat tindak pidana hanya akan dipidana jika ia mempunyai kesalahan dalam melakukan tindak pidana tersebut. ${ }^{27}$

Sudarto menyatakan "dipidananya seseorang tidaklah cukup apabila orang itu telah melakukan perbuatan yang bertentangan dengan hukum atau bersifat melawan hukum. Jadi meskipun perbuatan tersebut memenuhi rumusan delik dalam Undang-Undang dan tidak dibenarkan, Namun hal tersebut belum memenuhi syarat untuk penjatuhan pidana. Untuk pemidanaan masih perlu adanya syarat untuk penjatuhan pidana. Untuk pemidanaan masih perlu adanya syarat, bahwa orang yang melakukan perbuatan itu mempunyai kesalahan atau bersalah. Dengan perbuatan lain, orang tersebut harus dapat dipertanggungjawabkan atas perbuatannya atau jika dilihat dari sudut perbuatannya perbuatannya baru dapat dipertanggungjawabkan kepada orang tersebut". 28

Dalam Rancangan KUHP Pasal 32 ayat (2) dimungkinkan dalam hal tertentu seseorang dapat dipertanggungjwabakan atas tindak pidana yang dilakukan oleh orang lain, jika ditentukan dalam suatu Undang-Undang. Ketentuan ini merupakan pengecualian

${ }^{27}$ Dwidja Priyatno, Kebijakan Legislasi Tentang Sistem Pertanggungjawaban Pidana Korporasi Di Indonesia, Bandung : CV Utomo, 2004, hlm. 30

${ }^{28} \mathrm{Ibid}, \mathrm{hlm} .31$ 
dari asas tiada pidana tanpa kesalahan. Dalam hal-hal tertentu tanggungjawab seseorang dipandang patut diperluas sampai kepada tindakan bawahannya yang melakukan pekerjaan atau perbuatan untuknya atau dalam batas-batas perintahnya. Oleh karena itu meskipun dalam kenyataannya orang tidak melakukan tindak pidana namun dalam rangka pertanggungjawaban pidana ia dipandang mempunyai kesalahan jika perbuatan orang lain yang berada dalam kedudukan yang sedemikian itu merupakan tindak pidana.

Asas pertanggungjawaban yang bersifat pengecualian ini dikenal dengan asas "Vicarious Liability" sering diartikan pertanggungjawaban menurut hukum seseorang atas perbuatan salah yang dilakukan oleh orang lain. $^{29}$

Dalam KUHP memang tidak ada rumusan yang tegas tentang kemampuan bertanggungjawab pidana. Pasal 44 ayat (1) KUHP justru merumuskan tentang keadaan mengenai bilamana seseorang tidak mampu bertanggungjawab agar tidak dipidana, artinya merumuskan kebalikan secara negative dari kemampuan bertanggungjawab.

Dua keadaan jiwa yang tidak mampu bertanggungjawab sebagaimana yang dirumuskan didalam Pasal 44 ayat (1) KUHP, yakni jiwanya cacat dalam pertumbuhannya dan jiwanya terganggu karena penyekit. Orang yang dalam keadaan demikian jika melakukan tindak pidana tidak boleh dipidana Adapun pertanggungjawaban pidana bagi pelaku perdagangan orang menurut KUHP akan dijelaskan sebagai berikut :

${ }^{29}$ Ibid, hlm. 49 
5.3.2.1.1. Orang yang secara tunggal perbuatannya mewujudkan tindak pidana perdagangan orang.

Ancaman pidana yang dapat dijatuhkan pada orang ini adalah pidana penjara paling lama dua belas tahun (berdasarkan Pasal 324 KUHP,) pidana penjara paling lama delapan tahun. (Pasal 333 ayat 1), pidana penjara paling lama sembilan tahun (Pasal 333 ayat 2), pidana penjara paling lama dua belas tahun (Pasal 333 ayat 3), pidana penjara paling lama enam tahun (Pasal 297), pidana penjara paling lama sembilan tahun (Pasal 289), pidana penjara paling lama satu tahun empat bulan atau pidana denda paling banyak seribu rupiah (Pasal 296), pidana kurungan paling lama satu tahun. (Pasal 506).

5.3.2.1.2. Orang yang disebut dengan para pembuat (Mede dader) yang dalam mewujudkan tindak pidana perdagangan orang terlibat banyak orang dan terdiri dari empat bentuk yaitu orang yang melakukan (pleger), orang yang menyuruh melakukan (doen pleger), orang yang turut serta melakukan (mede pleger), orang yang menganjurkan (uitloker). orang ini melakukan perbuatan yang 
dipertanggungjawaban sama seperti pembuat tunggal.

Ancaman pidana yang dapat dijatuhkan pada orang ini adalah pidana penjara paling lama dua belas tahun (berdasarkan Pasal 324 KUHP), pidana penjara paling lama delapan tahun.(Pasal 333 ayat 1 ), pidana penjara paling lama sembilan tahun (Pasal 333 ayat 2), pidana penjara paling lama dua belas tahun (Pasal 333 ayat 3), pidana penjara paling lama enam tahun (Pasal 297), pidana penjara paling lama sembilan tahun (Pasal 289), pidana penjara paling lama satu tahun empat bulan atau pidana denda paling banyak seribu rupiah (Pasal 296), pidana kurungan paling lama satu tahun. (Pasal 506).

5.3.2.1.3. Orang yang disebut dengan pembuat pembantu (Medeplichtige), baik membantu pada saat kejahatan dilakukan maupun sebelum kejahatan dilakukan.

Ancaman pidana yang dapat dijatuhkan pada orang ini adalah maksimum pidana pokok terhadap kejahatan dapat dikurangi sepertiga (berdasarkan Pasal 57 ayat 1 ). Jadi pidana seperti yang telah disebutkan dalam Pasal 324, 333 (1) (2) (3), 297, 289, 296, dan 506 dikurangi sepertiga.

Dalam KUHP terkait dengan tindak pidana perdagangan orang yaitu dalam Pasal 333 ayat (4) ada pengecualian terhadap pertanggungjawaaban pidana 
pembantu dimana pembantu dipidana sama dengan pembuat. Pasal 333 ayat (4) adalah membantu dengan sengaja memberi tempat untuk perampasan kemerdekaan yang melawan hukum. Ancaman pidana yang dapat dijatuhkan pada pembantu ini adalah sama dengan pembuat yang melakukan tindak pidana dalam Pasal 333 (1), (2), (3) yaitu pidana penjara paling lama delapan tahun, sembilan tahun, dan dua belas tahun, tidak dijatuhi maksimum pidana pokok terhadap kejahatan dikurangi sepertiga

Pasal-Pasal dalam KUHP sebagaimana tersebut diatas berkaitan dengan pertanggungjawaban pidana bagi pelaku perdagangan orang memiliki banyak kelemahan yaitu :

5.3.2.1.1. Pasal 324 dapat dipergunakan untuk menjaring sebagian perbuatan perdagangan orang karena Pasal ini melarang perbuatan yang dapat dikategorikan sebagai perdagangan manusia, Namun obyeknya disebutkan secara khusus yaitu budak belian sehingga keberlakuan Pasal ini menjadi sempit sekali.

5.3.2.1.2. Upaya penuntutan kepada para germo yang sering berlaku sebagai trafficker menggunakan Pasal 333 KUHP tentang 'merampas kemerdekaan seseorang' juga sulit dilakukan, karena 'anak asuhan' nya bersedia memberikan pernyataan tertulis bahwa mereka 
datang atas kemauan sendiri dan seiijin orang tua.

5.3.2.1.3. Pasal 289, Pasal 296 dan Pasal 506 yang mengatur kegiatan pelacuran dimana Pasal-Pasal KUHP tersebut masih memerlukan suatu penafsiran bahwa pelacuran adalah perbuatan cabul sehingga dapat dianggap sebagai kejahatan terhadap kesusilaan atau pelanggaran terhadap ketertiban umum. Sebagaimana tertera dalam Pasal-Pasal tersebut di atas, maka kegiatan pemilik bordil atau pengelola, pelanggan, germo, dan penyelenggara yang seringkali melakukan tindak kekerasan, ancaman (secara halus), pemaksaan dan menyediakan fasilitas untuk berlangsungnya pelacuran telah dikriminalisasikan, Namun ancaman hukumannya sangat ringan (1 tahun, 1 tahun 4 bulan, paling lama 9 tahun atau denda) sehingga tidak mempunyai efek jera bagi pelakunya.

5.3.2.2. Undang-Undang Nomor 21 Tahun 2007 tentang Pemberantasan Tindak Pidana Perdagangan Orang.

Seperti yang telah dijelaskan diatas bahwa dalam KUHP dan Undang-Undang Nomor 21 Tahun 2007 tidak dikenal pengertian pertanggungjawaban pidana. oleh kerena itu pengertian tersebut harus dicari dalam dunia ilmu hukum (doktrin). 
Dalam hal pertanggungjawaban pidana unsur yang paling fondamental adalah unsur kesalahan, sebab orang atau korporasi tidak dapat diminta pertanggungjawaban kalau tanpa adanya suatu kesalahan. Dalam hal ini berkaitan dengan tindak pidana perdagangan orang tentunya kesalahan yang dimaksud berkaitan dengan pelanggaran terhadap ketentuan KUHP dan UndangUndang Nomor 21 Tahun 2007. Dalam Undang-Undang tersebut, terdapat klasifikasi tindak pidana perdagangan orang, yaitu tindak pidana materiil dan tindak pidana formil yang keduanya telah terdapat dalam Bab II

Untuk mengetahui Pertanggungjawaban pidana bagi pelaku perdagangan orang dalam Undang-Undang Nomor 21 Tahun 2007, maka perlu mengklasifikasikannya dalam beberapa bagian :

5.3.2.2.1. Bagian pertama yaitu mereka yang disebut dengan pelaku (Trafficker). Mereka yang disebut dengan (Trafficker) antara lain :

a) Perusahaan perekrut tenaga kerja dengan jaringan agen atau calo-calonya di daerah adalah trafficker manakala mereka memfasilitasi pemalsuan KTP dan paspor serta secara ilegal menyekap calon pekerja migran di penampungan, dan menempatkan mereka dalam pekerjaan yang berbeda atau secara paksa memasukkannya ke industri seks.

b) Agen atau calo-calo bisa orang luar tetapi bisa juga seorang tetangga, teman, atau bahkan kepala desa, yang dianggap trafficker manakala dalam perekrutan 
mereka menggunakan kebohongan, penipuan, atau pemalsuan dokumen.

c) Aparat pemerintah adalah trafficker manakala terlibat dalam pemalsuan dokumen, membiarkan terjadinya pelanggaran dan memfasilitasi penyeberangan melintasi perbatasan secara ilegal.

d) Majikan adalah trafficker manakala menempatkan pekerjanya dalam kondisi eksploitatif seperti: tidak membayar gaji, menyekap pekerja, melakukan kekerasan fisik atau seksual, memaksa untuk terus bekerja, atau menjerat pekerja dalam lilitan utang.

e) Pemilik atau pengelola rumah bordil, berdasar Pasal 289, 296, dan 506 KUHP, dapat dianggap melanggar hukum terlebih jika mereka memaksa perempuan bekerja di luar kemauannya, menjeratnya dalam libatan utang, menyekap dan membatasi kebebasannya bergerak, tidak membayar gajinya, atau merekrut dan mempekerjakan anak (dibawah 18 tahun).

f) Calo pernikahan adalah trafficker manakala pernikahan yang diaturnya telah mengakibatkan pihak isteri terjerumus dalam kondisi serupa perbudakan dan eksploitatif walaupun mungkin calo yang bersangkutan tidak menyadari sifat 
eksploitatif pernikahan yang akan dilangsungkan.

g) Orang tua dan sanak saudara adalah trafficker manakala mereka secara sadar menjual anak atau saudaranya baik langsung atau melalui calo kepada majikan di sektor industri seks atau lainnya. Atau jika mereka menerima pembayaran di muka untuk penghasilan yang akan diterima oleh anak mereka nantinya. Demikian pula jika orang tua menawarkan layanan dari anak mereka guna melunasi utangnya dan menjerat anaknya dalam libatan utang.

h) Suami adalah trafficker manakala ia menikahi perempuan tetapi kemudian mengirim isterinya ke tempat lain untuk mengeksploitirnya demi keuntungan ekonomi, menempatkannya dalam status budak, atau memaksanya melakukan prostitusi.

Ancaman pidana yang dapat dijatuhkan kepada pelaku (trafficker) tersebut di atas antara lain :

5.3.2.2.1. Untuk pelaku setiap orang (orang perorangan dan korporasi) yang melakukan tindak pidana perdagangan orang. Ancaman pidana yang dapat dijatuhkan kepada mereka adalah :

a) Pidana penjara paling singkat 3 tahun dan paling lama 15 tahun dan denda paling sedikit 120 juta rupiah dan paling banyak 
600 juta rupiah (berdasarkan Pasal 2-6 UU RI NO. 21 TAHUN 2007),

b) Ancaman pidana dapat ditambah sepertiga dari ancaman pidana dalam Pasal 2 ayat (2), Pasal 3, Pasal 4, Pasal 5, Pasal 6 jika tindak pidana sebagaimana dimaksud dalam Pasal 2, Pasal 3, Pasal 4, Pasal 5, Pasal 6 mengakibatkan korban menderita luka berat, gangguan jiwa berat, penyakit ,menular lainnya yang membahayakan jiwanya, kehamilan, atau terganggu atau hilangnya fungsi reproduksinya (berdasarkan Pasal 7 ayat (1) UU RI NO. 21 TAHUN 2007).

c) Dipidana dengan pidana penjara paling singkat 5 tahun dan paling lama penjara seumur hidup dan denda paling sedikit 200 juta rupiah dan paling banyak 5 milyar rupiah. Jika tindak pidana sebagaimana dimaksud dalam Pasal 2 ayat (2), Pasal 3, Pasal 4, Pasal 5, Pasal 6 mengakibatkan matinya korban, (berdasarkan Pasal 7 ayat (2) UU RI NO. 21 TAHUN 2007).

d) Ancaman pidanannya ditambah 1/3 (sepertiga) Jika tindak pidana sebagaimana dimaksud dalam Pasal 2, Pasal 3, dan Pasal 4 dilakukan terhadap anak (berdasarkan Pasal 17 UU RI NO. 21 TAHUN 2007).

e) Dalam hal tindak pidana perdagangan orang dilakukan oleh suatu korporasi, selain pidana penjara dan denda terhadap 
pengurusnya, juga dapat dijatuhkan pidana terhadap korporasi berupa pidana denda dengan pemberatan tiga kali dari pidana denda sebagaimana dimaksud dalam Pasal 2, Pasal,3, Pasal 4, Pasal 5, dan Pasal 6. (berdasarkan Pasal 15 ayat (1) UU RI NO. 21 TAHUN 2007).

f) Korporasi dapat dijatuhi pidana tambahan berupa : pencabutan izin usaha, perampasan hasil kekayaan hasil tindak pidana, pencabutan status badan hukum, pemecatan pengurus dan atau pelarangan kepada pengurus tersebut untuk mendirikan korporasi dalam bidang usaha yang sama (berdasarkan Pasal 15 ayat (2) UU RI No. 21 Tahun 2007).

5.3.2.2.2. Untuk pelaku aparat (penyelengara negara). Ancaman pidana yang dapat dijatuhkan :

(1) Pidananya ditambah sepertiga dari ancaman pidana dalam Pasal 2, Pasal 3, Pasal 4, Pasal 5, dan Pasal 6. (berdasarkan Pasal 8 ayat (1) UU RI No. 21 Tahun 2007).

(2) Pidana tambahan berupa pemberhentian secara tidak hormat dari jabatannya (berdasarkan Pasal 8 ayat (2) UU RI No. 21 Tahun 2007).

5.3.2.2.3. Untuk pelaku yang berupa kelompok terorganisasi. Ancaman pidana yang dapat dijatuhkan adalah pidana yang sama sebagaimana dimaksud dalam Pasal 2 ditambah 
1/3 (sepertiga) (berdasarkan Pasal 16 UU RI NO. 21 TAHUN 2007).

5.3.2.2.2. Bagian kedua yaitu mereka yang disebut dengan pengguna (usser) perdagangan orang baik yang secara langsung mengambil keuntungan dari korban, maupun yang tidak langsung melakukan eksploitasi. Mereka yang disebut dengan pengguna (usser) antara lain :

1) Germo dan pengelola rumah bordil yang membutuhkan perempuan dan anak-anak untuk dipekerjakan sebagai pelacur.

2) Laki-laki hidung belang, pengidap pedofilia dan kelainan seks lainnya serta para pekerja asing (ekspatriat) dan pebisnis internasional yang tinggal sementara di suatu negara.

3) Para pengusaha yang membutuhkan pekerja anak yang murah, penurut, mudah diatur dan mudah ditakut-takuti.

4) Pengusaha bisnis hiburan yang memerlukan perempuan muda untuk dipekerjakan di panti pijat, karaoke dan tempat-tempat hiburan lainnya.

5) Para pebisnis di bidang pariwisata yang juga menawarkan jasa layanan wisata seks.

6) Agen penyalur tenaga kerja yang tidak bertanggung jawab.

7) Sindikat narkoba yang memerlukan pengedar baru untuk memperluas jaringannya. 
8) Keluarga menengah dan atas yang membutuhkan perempuan dan anak untuk dipekerjakan sebagai pembantu rumah tangga.

9) Keluarga yang ingin mengadopsi anak.

10) Laki-laki China dari luar negeri yang menginginkan perempuan "tradisionil" sebagai pengantinnya.

5.3.2.2.3. Bagian ketiga yaitu mereka yang disebut Penganjur (Uitlokker) dan atau menyuruhlakukan (Doenpleger), atau biasa disebut dengan orang yang mengerakkan supaya melakukan tindak pidana perdagangan orang sebagaimana halnya yang dimaksud dalam Pasal 55 KUHP.

5.3.2.2.4. Bagian keempat yaitu mereka yang disebut orang yang turut serta melakukan (Mede pleger) sebagaimana halnya yang dimaksud dalam Pasal 55 (1) ke-1 KUHP.

5.3.2.2.5. Bagian kelima yaitu mereka yang disebut Membantu melakukan (Medeplichtigheid), membantu pelaku tindak pidana perdagangan orang tidak hanya pada saat dan sebelum kejahatan dilakukan tetapi juga setelah kejahatan dilakukan.

Ancaman pidana yang dapat dijatuhkan kepada orang yang membantu pelaku tindak pidana perdagangan orang pada saat dan sebelum kejahatan dilakukan adalah dipidana dengan pidana yang sama sebagai pelaku sebagaimana dimaksud dalam Pasal 2, Pasal 3, 
Pasal 4, Pasal 5, Pasal 6 yaitu pidana penjara paling singkat 3 tahun dan paling lama 15 tahun dan denda paling sedikit 120 juta rupiah dan paling banyak 600 juta rupiah (berdasarkan Pasal 10 UU RI NO. 21 TAHUN 2007).

Ancaman pidana yang dapat dijatuhkan kepada orang yang membantu pelaku tindak pidana perdagangan orang setelah kejahatan dilakukan (membantu pelarian) pelaku tindak pidana perdagangan orang dari proses peradilan pidana dengan cara memberikan atau meminjamkan uang, barang, atau harta benda, atau harta kekayaaan lainnya kepada pelaku, menyediakan tempat tinggal bagi pelaku, menyembunyikan pelaku atau, memyembunyikan informasi keberadaan pelaku adalah dipidana dengan pidana penjara paling singkat 1 tahun dan paling lama 5 tahun dan pidana denda paling sedikit 40 juta rupiah dan paling banyak 200 juta rupiah (berdasarkan Pasal 23 UU RI NO. 21 TAHUN 2007).

Ketentuan tentang pembantuan pada Pasal 10 dan 23 tersebut juga merupakan ketentuan khusus yang menyimpang dari ketentuan KUHP. Dimana dalam KUHP disebutkan dalam Pasal 57 ayat (1) yang menyatakan bahwa dalam hal pembantuan maksimum pidana pokok terhadap kejahatan, dikurangi sepertiga. 
Dalam analisa perbandingan ini antara KUHP dan UU RI NO. 21 Tahun 2007 berkaitan tentang "pertanggungjawaban pidana" bagi pelaku tindak pidana perdagangan orang, dibedakan menjadi dua yaitu : persamaan dan perbedaan.

\subsubsection{Analisa persamaan}

Dalam KUHP dan Undang-undang Nomor 21 tahun 2007 berkaitan tentang "pertanggungjawaban pidana" bagi pelaku tindak pidana perdagangan orang mempunyai persamaan, yaitu : Bahwa dalam KUHP dan Undang-undang Nomor 21 tahun 2007 dalam hal pertanggungjawaban pidana unsur yang paling fondamental adalah unsur kesalahan, sebab orang atau korporasi tidak dapat diminta pertanggungjawaban kalau tanpa adanya suatu kesalahan. Dalam hal ini berkaitan dengan tindak pidana perdagangan orang tentunya kesalahan yang dimaksud berkaitan dengan pelanggaran terhadap ketentuan KUHP dan UU Undang-undang Nomor 21 tahun 2007

\subsubsection{Analisa perbedaan}

1) Pertanggungjawaban pidana" bagi pelaku tindak pidana perdagangan orang dalam Undang-undang Nomor 21 tahun 2007 dinyatakan secara tegas dan jelas mengenai ancaman pidana atau sanksi pidananya terhadap pelaku tindak pidana perdagangan orang. Sanksi yang diancamkan kepada pelaku lebih berat dibandingkan dengan KUHP. Pasal-Pasal dalam KUHP tidak memberikan sanksi yang tegas dan terlalu ringan serta mempunyai banyak kelemahan-kelemahan sehingga sulit untuk 
menjerat para pelaku perdagangan orang. Dalam Undang-undang Nomor 21 tahun 2007 dicantumkan pidana penjara minimal dan maksimal serta denda maksimal dan minimal terhadap pelakunya sesuai dengan penggolongan pelaku, sedangkan dalam KUHP hanya dicantumkan pidana maksimalnya dan tidak dicantumkan pidana minimalnya terhadap pelakunya karena ketentuan pidana minimal telah diatur secara tersendiri dalam Buku Ke-satu (aturan umum).

2) Berkaitan tentang "pertanggungjawaban pidana" bagi pelaku tindak pidana perdagangan dalam Undang-undang Nomor 21 tahun 2007 terdapat ketentuan khusus yang berbeda dengan KUHP yaitu dalam hal pembantuan. Ketentuan tentang pembantuan pada Pasal 10 dan 23 dalam Undangundang Nomor 21 tahun 2007 tersebut merupakan ketentuan khusus yang menyimpang dari ketentuan KUHP. Dimana dalam KUHP disebutkan dalam Pasal 57 ayat (1) yang menyatakan bahwa dalam hal pembantuan maksimum pidana pokok terhadap kejahatan, dikurangi sepertiga sedangkan dalam Pasal 10 Undang-undang Nomor 21 tahun 2007 pembantu dipidana dengan pidana yang sama sebagai pelaku sebagaimana dimaksud dalam Pasal 2, Pasal 3, Pasal 4, Pasal 5, Pasal 6 yaitu pidana penjara paling singkat 3 tahun dan paling lama 15 tahun dan denda paling sedikit 120 juta rupiah dan paling banyak 600 juta rupiah. Kemudian dalam Pasal 23 Undang-undang Nomor 21 tahun 2007 pembantu dipidana dengan pidana penjara paling singkat 1 
tahun dan paling lama 5 tahun dan pidana denda paling sedikit 40 juta rupiah dan paling banyak 200 juta rupiah.

\section{Kesimpulan}

Pertanggung jawaban pidana delik perdagangan orang dalam KUHP adalah pelaku tindak pidana perdagangan orang terdiri dari : (1) pembuat tunggal (dader), (2) para pembuat (Mede dader) yang terdiri dari empat bentuk sebagaimana disebut dalam pasal 55 ayat (1) KUHP yaitu : orang yang melakukan (pleger), orang yang menyuruh melakukan (doen pleger), orang yang turut serta melakukan (mede pleger),orang yang menganjurkan (uitloker). (3) pembuat pembantu (Medeplichtige) yaitu pada saat kejahatan dilakukan dan sebelum kejahatan dilakukan.

Pertanggung jawaban pidana delik perdagangan orang dalam UndangUndang RI Nomor 21 Tahun 2007 adalah pelaku tindak pidana perdagangan orang dapat berupa "orang" (Manusia) atau suatu "Korporasi", sedangkan pelaku tindak pidana perdagangan orang dalam KUHP hanya terbatas pada "manusia". Perbedaan yang lain adalah mengenai pembagian golongan pelaku tindak pidana perdagangan orang. Sedangkan menurut Undang-undang Nomor 21 tahun 2007 pelaku tindak pidana perdagangan orang terdiri dari : (1) Setiap orang yang terdiri dari Orang perorangan dan korporasi, (2) Penyelengara negara, (3) Penganjur (Uitlokker) dan atau menyuruhlakukan (Doen pleger), (4) Pembantu (Medeplichtigheid), pembantuan tidak hanya sebelum atau pada saat kejahatan perdagangan orang dilakukan tetapi juga sesudah kejahatan perdagangan orang, (5) orang yang turut melakukan (Mede pleger), (6) Pengguna, (7) Kelompok terorganisasi.

Komparasi pertanggung jawaban pidana delik perdagangan orang dalam KUHP dan Undang-Undang RI Nomor 21 Tahun 2007 adalah baik dalam KUHP dan UU RI NO 21 TAHUN 2007 sama-sama mengenal pelaku perdagangan orang yang berbentuk tunggal (orang perorangan), para pembuat (Mede dader) yang dalam mewujudkan tindak pidana perdagangan orang 
terlibat banyak orang, dan pelaku pembantu dalam tindak pidana perdagangan orang. Sedangkan perbedaannya adalah dalam Dengan demikian dapat dikatakan bahwa dalam KUHP tidak dikenal subyek tindak pidana atau pelaku tindak pidana perdagangan orang yang berupa korporasi, penyelengara negara, pembantu sesudah kejahatan perdagangan orang, pengguna, dan kelompok yang terorgansiasi. 


\section{DAFTAR PUSTAKA}

\section{Peraturan Perundang-Undangan}

Kitab Undang-Undang Hukum Pidana

Undang-Undang Republik Indonesia Nomor 21 Tahun 2007 tentang Pemberantasan Tindak Pidana Perdagangan Orang.

\section{Literatur Ilmiah}

Chazawi, Adami, Pelajaran Hukum Pidana Bagian 2, Jakarta : PT Raja Grafindo Persada, 2002.

Lamintang, P.A.F, Dasar-Dasar Hukum Pidana Indonesia. Bandung. PT Citra Aditya Bakti, 1997.

Moeljatno, Asas-Asas Hukum Pidana, Jakarta : Rineka Cipta, 1993.

Nawawi, Barda Arief, Sari Kuliah Hukum Pidana II, Semarang : Badan Penyediaaan Bahan Kuliah Fakultas Hukum Universitas di Ponegoro, 1993.

Penjelasan Undang-Undang Nomor 21 Tahun 2007 tentang Pemberantasan Tindak Pidana Perdagangan Orang

Priyatno, Dwidja, Kebijakan Legislasi Tentang Sistem Pertanggungjawaban Pidana Korporasi Di Indonesia. Bandung : CV Utomo, 2004.

Saleh, Roeslan, Perbuatan Pidana dan Pertanggungjawaban Pidana. Jakarta : Aksara Baru, 1993.

Soekanto, Soerjono dan Sri Mamudji, Penelitian Hukum Normatif (Suatu Tinjauan Singkat). Jakarta : Raja Grafisindo Persada, 2003.

Soekanto, Soerjono, Pengantar Penelitian Hukum. Jakarta : Universitas Indonesian Press, 1984.

Sunggono, Bambang, Metode Penelitian Hukum. Jakarta : PT Raja Grafindo Persada, 1997.

Sutopo, Heribertus, pengantar penelitian kualitatif. Surakarta : Puslitbang UNS, 1998. 